\title{
Forms of measurement of the income and the consequences in the calculation of the ROA
}

\author{
Dione Olesczuk Soutes * \\ University de São Paulo \\ Eliandro Schvirck ** \\ Federal Technology University of Paraná
}

\begin{abstract}
The objective of this study is to analyze which the consequences in the ROA (Return on Assets), when of the use of different forms of measurement of the income. The forms of measurement, approached in this work, are: the accounting operational income, comprehensive income and net income. The North American accounting standards (US GAAP) make possible the use of the two first forms while what and the Brazilian legislation (Lei 6.404/76) establishes the application of third. The work present the three forms of measurement of the income aiming at to answer which the consequences in the ROA for the use of different forms of measurement of income? The main similarities and differences between the three concepts inhabit in the following aspects: value of measurement of the costs and expenditures; consideration of extraordinary items as integrant of the result or of the Equity; the accounting treatment of deriving contributions of not controlling shareholders or of third with characteristics of capital reserve. The ROA is calculated from the income presented for the company, and then the form of used measurement will influence the analysis of this pointer.
\end{abstract}

Keywords: income measurement, return on investments, extraordinary items.

Received in 12/11/2005; revised in 30/12/2005; accept in 03/03/2006.

Corresponding authors:

Dione Olesczuk Soutes

Doutor em Controladoria e Contabilidade

Universidade de São Paulo

Adress: Av. Prof. Luciano Gualberto, 908 - Prédo III,

Cidade Universitária, 05508900 - Sao Paulo, SP -

Brasil

Email: dioneosoutes@hotmail.com

Telephone: (45) 32847878
Eliandro Schvirck

Doutor em Administração

Universidade Tecnológica Federal do Paraná

Adress: Via do Conhecimento km 01, Fraron, 85503390 - Pato

Branco, PR - Brasil - Caixa-postal: 571

Email: eliandrosc@gmail.com

Telephone: (46) 32202527 


\section{INTRODUCTION}

he development of companies is leveraged by investors, but for this to occur they $\mathrm{T}$ must have positive expectations and confidence. Companies, of course, do their utmost to achieve good results and investors seek alternatives that best meet their expectations.

An investment decision is generally made after examining some performance indicators and aspects, among them: the activities the company is engaged in, its indebtedness, risk of return, net present value of the investment, return on investment, and so on. Among the indices commonly used by investors and analysts, according to Rappaport, cited in Frezatti (2005), the most often used by the market is Return on Investment (ROI). This indicator is obtained from the company's income (profit), which can be calculated in different ways, considering the aim of the specific indicator. Besides ROI, two more are Return on Equity (ROE) and Return on Assets (ROA). All three of these use the profit shown in the financial statements to measure how the capital invested is rewarded.

The American Institute of Accounts (AIA), cited by Hendriksen and Van Breda (1999, p. 61), argues that the yardstick that interests users, and particularly investors, is "(...) the 'ability to generate profit' expected of the company, defined as the ordinary income excluding extraordinary profits or losses, determined in a uniform way from year to year and company to company." The definition of ordinary income was the same as that given for current operating income, and this, as presented by Hendriksen and Van Breda (1999, p. 61), tempted managers, "(...) on many occasions to consider all gains as ordinary and all losses as extraordinary." This led the Securities and Exchange Commission (SEC) and the AIA to seek a more extensive measure of profit. Because of this, the Financial Accounting Standards Board (FASB), the body responsible for accounting regulation in the United States, issued Statement of Accounting Standard (SFAS) 130 - Reporting Comprehensive Income, in June 1997, regulating the disclosure of comprehensive income of American companies.

Another way of presenting companies' results is discussed by Edwards and Bell (1973), denominated current operating income, which because of the difficulties of determining current values, was adapted to show the accounting income. These two ways of preparing financial statements set forth in the United States complement each other and have different objectives and theoretical grounds. The first is based on the economic concept of profit, the variation in wealth, while the second is based on the concept of maximizing income.

Brazilian legislation, specifically Law 6404/76 (the basic Law of Corporations), determines the way of presenting profit, mixing the two concepts presented above, so that the result obtained neither demonstrates the generation of wealth nor the maximization of the result. This makes it hard to evaluate the performance of Brazilian companies under either of these lights.

In this context, the present study analyzes what the reflections are on ROA of using different ways of measuring profit.

In order to show the effects on the ROA by measuring income in its different forms, we used data on eight Brazilian companies, chosen from the list disclosed by the magazine Melhores e Maiores ("Best and Biggest") for July 2004. The chosen firms were all considered by the ranking as the best or largest in their sectors in 2003. Companies not listed on the São Paulo Stock Exchange (Bovespa) were eliminated. 
Considering what the literature says, as well as the purposes of this work, it can be considered an exploratory study regarding the theoretical and empirical objectives and the procedures.

Regarding the approach to the problem, this study is qualitative, since based on Cortes (In BÊRNI, 1992, p. 237), the quantitative approach "(...) enables describing the qualities of determined phenomena or objects of study." Hence, the purpose of this work is in part to gain an understanding of the reflections of different ways of measuring profit on ROA.

The text is organized as follows. The next section examines ways of measuring profit, followed by a section analyzing ways of reporting profit according to American and Brazilian legislation. Then there is an explanation of ROA, followed by the accounting information of the selected firms, and the ROA is calculated employing the three ways of measuring profit.

\section{WAYS OF MEASURING PROFIT}

Determining a company's result depends on the evaluation of its assets, i.e., measurement of the facts occurred. Hendriksen and Van Breda (1999, p. 60) present situations where there are alternative ways of accounting, among them: valuation of inventories: first in, first out (FOFO) versus last in, first out (LIFO); depreciation and depletion: fiscal versus accounting; investments in related companies: historic cost versus equity value, etc. The choice of one of these alternatives affects the bottom line result.

Regarding profit, a company's positive result, Hendriksen and Van Breda (1999, p.

181) state that "(...) based on economic concepts, profit in accounting terms can be defined in two ways." The first is through "(...) maximizing the profit under specified conditions of market, product demand and production cost factors"; and the second is by preservation of the capital.

The FASB, in its Statement of Financial Accounting Concepts (SFAC) 1, presents the concept of profit maximization as follows: "The test of success (or failure) of the operations of an enterprise is the extent to which the cash returned exceeds (or is less than) the cash spent (invested) over the long run." (SFAC 1, in HENDRIKSEN; VAN BREDA, 1999, p. 181). SFAC 6 makes the concept of preservation of capital explicit: "Comprehensive income is the change in the equity of a business enterprise during a period (...)" (SFAC 6, In: HENDRIKSEN; VAN BREDA, 1999, p. 181).

From the definitions of the FASB, it is possible to conceive various ways of determining profit. One of them, the most common, is to subtract from revenues all the costs and expenses necessary to generate them, with the result called profit when positive and loss when negative. Another form is to determine the amount of net equity at the start of the period with that at the end of the period, excluding capital increases and adding the amount distributed as dividends. The result of this calculation is the profit or loss for the period.

At first glance these comparisons look simple, but in practice it is not so simple. To determine the amount of revenues, costs and expenses in a period, accrual method accounting must be used and then a judgment must be made whether the values booked are current or historic ones, whether accounting principles have changed during the period and what is the reflection of this on the revenues, costs and expenses, etc. In measuring the profit by the concept of preservation of capital, one needs to know whether this involves the physical capital or financial capital, the net value of the capital, etc.

The divergences regarding profit are not limited to the way of determining it. Another common difficulty is the definition of profit. Hendriksen and Van Breda (1999, p.182) present definitions of various authors. According to them, “(...) profit is the result obtained from the use of capital (...) while capital is seen as the stock of wealth able to generate future services, 
profit is the flow of wealth or benefits above that which is necessary to maintain the capital constant."

The Scottish economist Adam Smith, cited by Hendriksen and Van Breda (1999, p. 183), was the first to define profit as being the amount that could be consumed without reducing the capital. In other words, profit is the excess after maintaining welfare, but before consumption.

Leaving aside the difficulties in defining profit, the FASB, in SFAC 1, observes that the overarching goal of accounting is to permit shareholders and other individuals to form expectations about future cash flows. In the words of the FASB (SFAC 1, 1978, p. 5): "Financial reporting should provide information to help present and potential investors and creditors and other users in assessing the amounts, timing, and uncertainty of prospective cash receipts from dividends or interest and the proceeds from the sale, redemption, or maturity of securities or loans."

Seeking to meet the different objectives of measuring profit, American legislation allows it to be reported in two ways. The first, which it considers the result offered by the concept of maximization of profit, is the statement of current operating income. The second, which considers the concept of preservation of capital, is the statement of comprehensive income. Brazilian legislation (Law 6404/76) stipulates profit reporting by a mixture of the above two concepts. These different ways of disclosing profit are presented and discussed next.

\section{WAYS OF REPORTING PROFIT}

There are various groups that use the information generated by accountancy, each of them with a specific interest, and according to Hendriksen and Van Breda (1999, p. 200), these interests include: "1- the use of profit as a measure of the efficiency of the company's management; 2- the use of historic profit data as an instrument to predict the future behavior of the company or of future dividend payments; 3- the use of profit as a measure of the performance and orientation for future management decisions."

Law 6404/76, aiming to meet the objectives of the various groups of users, requires disclosure of a set of statements: the balance sheet, income statement, statement of accrued profits or losses (or statement of changes in stockholders' equity) and statement of changes in financial position. Considering the objectives of this work, our focus will be on the income statement.

Below the concepts are presented of accounting income, comprehensive income and net income. The first two are allowed by American legislation and the last is stipulated by Brazilian.

\section{ACCOUNTING INCOME}

Edwards and Bell (1973, pp. 110-15) first present the concept of current operating income, but as said before, this concept was modified to accounting income. According to the authors, this income should consist of four basic segments and the segregation of information is very different in different segments of the income statement, allowing users to extract the information according to their needs. The four basic segments of income (or profit) are:

A. Current operating income: the excess, in a period, of the current value of merchandise sold over the current cost related to this merchandise;

B. Retained realizable cost:: the increment in the current cost of assets held by the company during the accounting period;

C. Capital gain realized: the excess of revenues over costs on non-regular sales or writeoff of assets; 
D. Cost savings realized: the excess of current costs over historic costs of materials consumed in producing the merchandise sold.

According to Edwards and Bell, the accounting income is the sum of the current operating income, cost savings realized and capital gain realized. The argue that the accounting income brings the result obtained from the value of current revenues minus the amount of costs and expenses at their historic levels, thus hindering the correct disclosure of the value of the gains provided by management's running of the company. They also state $(1973$, p. 116) that so in this context it is not possible to evaluate a company's management by simply comparing the current sale value with accumulated costs that occurred at historic value. The figure below illustrates the authors' proposal to segregate the elements within the income statement for the period, permitting evaluation of the company's operations, management's activities and the overall result.

Figure 1 - Elements included in accounting income

\begin{tabular}{lll}
\hline & Elements included in income & \\
\cline { 2 - 3 } Accounting income $=$ & $\begin{array}{l}\text { As operating income } \\
(\mathrm{A}+\mathrm{D})\end{array}$ & $\mathrm{C}$ \\
\hline
\end{tabular}
Source: Edwards and Bell (1973, p. 116)

Further according to these authors (1973, p. 117), the utility of accounting income for management purposes suffers two basic limitations:

1. Gains realized through use are confused with operating income. This income that comes from maintaining assets is added to that coming from production.

2. Changes in the prices of assets maintained by the firm are not booked when they occur. Instead, such gains are credited to the period in which they are received, as the result of amounts on the balance sheet, meaning current costs are excluded.

To try to resolve these limitations, two concepts have been presented for showing income: current operating income and comprehensive income.

The term comprehensive income refers to the income obtained only by common shareholders, and was introduced by the FASB to cover items such as adjustments from previous periods, which although accounted for as a variation in retained earnings, perhaps should be considered as part of the current period's results.

The concept of current operating income focuses on measuring the company's efficiency. Only the variations in value and events controllable by management and that result from decisions in the period should be included.

Hendriksen and Van Breda (1999, p. 210) explain that supporters of the operating income concept often say that the operating items are generally defined as regular aspects of the company's operations, and that non-operating items are generally considered as irregular or unforeseeable. Differentiating between operating and non-operating is more useful to assess management's efficiency.

The advantage of classifying debits and credits as regular or extraordinary is supported by the increased utility to investors for purposes of predicting future performance. Hendriksen and Van Breda (1999, p. 210) argue that "(...) perhaps it is more difficult, for people outside the company, to distinguish between regular and extraordinary events." The Accounting Principles Board (APB) 30, cited by Iudícibus (2004, p.175), determined that, for transactions to be considered extraordinary, “(...) besides being material, they also need to be unusual and infrequent, in light of "the environment in which the enterprise operates."

The difference between the statement of accounting income and current operating income rests basically in the value booked as cost of merchandise sold. In the first, the cost is 
according to the historic value, and in the second, according to the current value on the date of sale. Other expenses are normally appropriated to the result at their current value at the date of consumption.

More significant differences are found between comprehensive and net income, the latter as stipulated by Brazilian law, to which we now turn.

\section{COMPREHENSIVE INCOME}

Another way of presentation is the statement of comprehensive income. In this, the profit is defined as the result of the common shareholders, which according to Hendriksen and Van Breda (1999, p.208), is obtained by the "(..) total variation in the value of the capital stock, recognized by the register of transactions and revaluation of the company during a determined period, except for payment of dividends and capital increases or decreases", besides the earnings of minority or preferred shareholders.

The FASB, through SFAC 3, paragraph 56, states that: "Comprehensive income is the change in equity (net assets) of an entity during a period from transactions and other events and circumstances from nonowner sources. It includes all changes in equity during a period except those resulting from investments by owners and distributions to owners."

According to Hendriksen and Van Breda (1999, pp. 209-10), an important difference between the current operating and comprehensive concepts of income is in the presumed object of the disclosure. Current operating income emphasizes the company's current performance or operating efficiency and it is possible to use this yardstick to predict the future performance and capacity to generate income. Supporters of comprehensive income say that judgment of both operating efficiency and future performance can be improved if these are based on the firm's historical experience, because the useful life of assets normally extends for more than one period and the transactions generating profit are not in uniform stages. In other words, the profit in a single period is, in the best of cases, an estimate based on a subjective, and thus preliminary, judgment, and this is always subject to verification at future dates.

Another situation that illustrates this difference pointed out by Hendriksen and Van Breda is that operating income can be compromised by the classification of operating and non-operating items, not permitting correct assessment of the company's operational activities. Besides this, there are also adjustments from past periods that are reflected on the result of the current one, a problem that does not exist for comprehensive income because all the changes in net equity are included, thus permitting a more complete evaluation of the firm's performance.

Also according to these authors (1999, p. 209), the elements composing comprehensive income are: current operating income, extraordinary items, accrued effect of changes in accounting principles on previous years and other variations in the capital stock not belonging to controlling owners. Figure 2 shows the structure and sequence of presentation of these elements. 
Figure 2 - Elements that compose comprehensive income

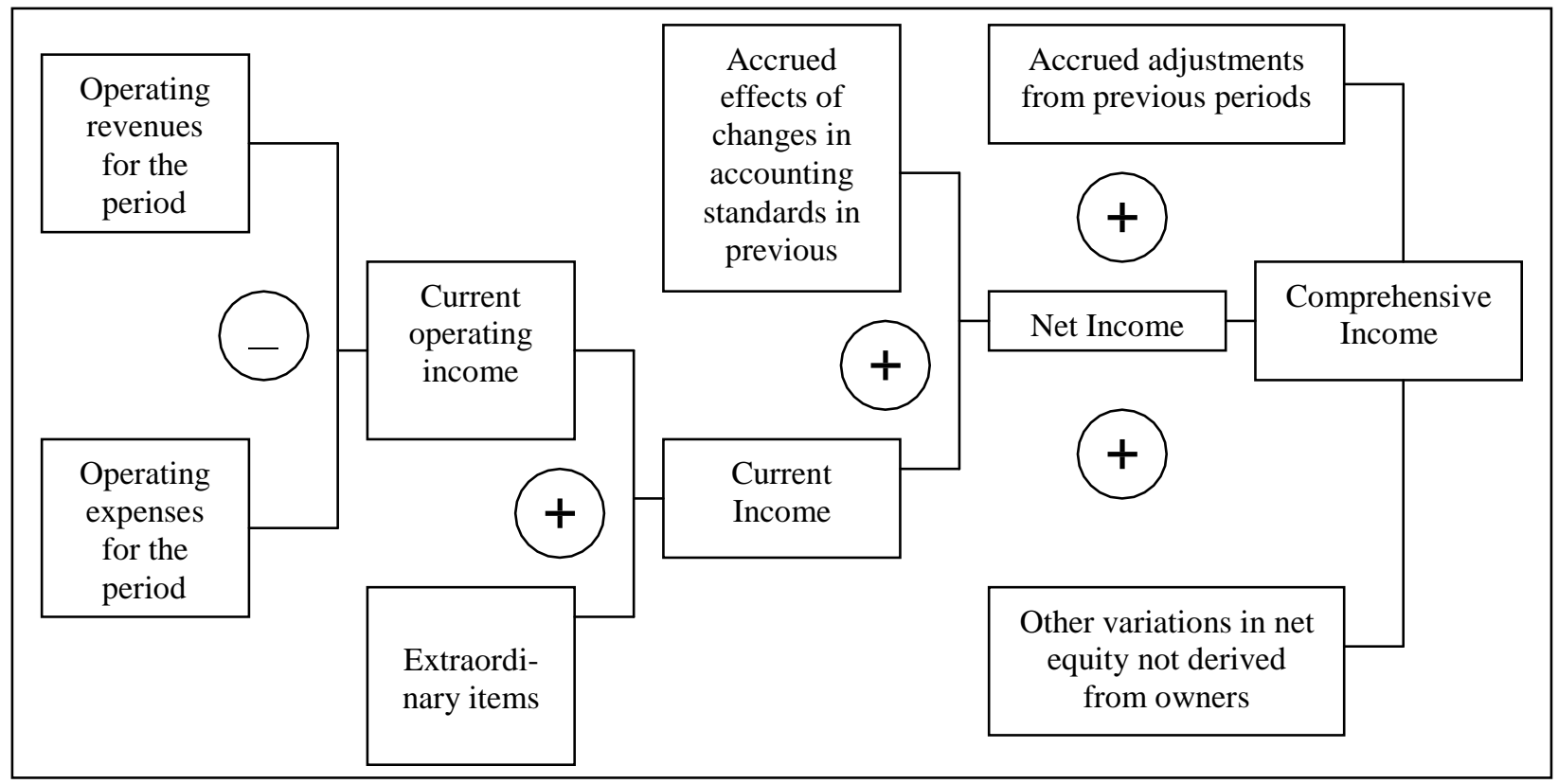

Source: Coelho, Galdi and Almeida, 2004. Notes from postgraduate class in accounting theory at FEA-USP.

The difference between this statement and the current operating income one is, in principle, the value of the cost of the products sold, which in comprehensive income is the same value presented in the accounting income, i.e., the historical value. Besides this difference, the comprehensive income statement includes extraordinary items such as: revenue from dividends from investments valued by the cost method, equity pick-up, results from disposal of fixed assets, revaluation of fixed assets net of income tax, adjustments from previous years, subsidies received, among others.

Besides the ways of presenting the results allowed by American regulation and discussed above, Brazilian legislation determines a third form, presented below.

\section{NET INCOME (LAW 6404/76)}

Law 6404, enacted in December 1976, determines some accounting standards and procedures in Brazil, among them the structure of the financial statements. This structure, if compared with that allowable under US GAAP, adopted a mixed form of reporting, because it blends the two American forms. According to Iudícibus (2004, p. 179), “(...) the Law [6404/76] took a mixed approach, perhaps tending more, at least in its intentions, to the "clean' concept." In the context of the discussion heretofore, the concept of "clean" refers to the current operating concept.

Brazilian legislation presents the expression net profit as a result of the income statement, which according to Reis $(2003$, p. 154), is "(...) the operating profit, plus extraoperational revenues (gains on disposal of permanent assets ${ }^{2}$ ), deducting extra-operational expenses (losses on disposal of permanent assets) and third party shares in the results, such as income tax or payments to employees and officers."

The statement of current operating income only deals with changes in value and events that are controllable by management and that result from decisions in the current period. The

\footnotetext{
${ }^{2}$ Permanent assets consist of fixed assets, fixed investments and deferred charges. This is a particularity of Brazilian GAAP.
}

BBR, Braz. Bus. Rev. (Eng. ed., Online),

Vitória, v. 3, n. 1, Art. 6, p. 73-85, jan.-jun. 2006

www.bbronline.com.br 
statement of comprehensive income, according to Iudícibus (2004, p. 176), “(..) requires recognizing in the period the reductions and additions to net equity that do not derive from capital transactions or dividend distributions" (original emphasis). The statement under Brazilian legislation, mixing the two concepts, uses the operating profit provided by the current operating income, but does not demand updating of the events accounted for by historic cost to current values.

The similarity between the comprehensive statement and the Brazilian one is that both present the amounts from extraordinary items and results of capital gains. The difference is that in comprehensive income all the events that effect the net equity, except capital transactions and dividend distributions, are shown, while by Brazilian legislation some events are presented in the results and others are not. As an example of events booked directly in net equity, there are:

Capital reserves from donations and subsidies;

Revaluation reserves from revaluation of permanent assets; and

Adjustments from previous years, which are booked directly in the accrued profit or loss account in net equity.

Having presented the three forms of showing profits, we now examine Return on Assets (ROA) to permit a discussion of the differences caused in the accounting information by the profit reporting choice.

\section{RATES OF RETURN ON INVESTMENT}

There are various forms of calculating the return on investments. Among them are Return on Investment (ROI), Return on Assets (ROA), Return on Equity (ROE) and Return on Net Assets (RONA). This study uses ROA, which according to Matarazzo (2003, p. 179) shows a firm's capacity to generate net profit and thus capitalize itself.

The rate of return on total assets, according to Gitman (2002, p. 123), “(...) measures the overall administration in generating profits with the available assets." As put by Kassai et al. (2002, p. 34), "ROA is the company' genuine rate of return, attributed to its capacity to generate earnings, regardless of its financing structure."

Marion (2001, p. 137) argues that the combination of assets is what generates revenue for the company, these being the investments made by the company to obtain revenue, and consequently profit. Hence, the rate of return on investment is given by comparing this profit with the assets that generate it. This represents the company's power to gain.

According to Gitman (2002, p. 123), Matarazzo (2003, p. 178), Silva (1995, p. 243), Zdanowicz (1998, p. 111) and Marion (2001, p. 138), the formula for calculating ROA is the following:

\section{Rate of return on assets $=$}

Net income after income tax

\section{Total assets}

Just as Gitman (2002) and Kassai et al. (1999), some authors consider that ROA and ROI present the same thing, but according to Reis (2003, p. 157), the difference between the two is in the denominator: "(...) in ROI, the denominator is formed of the operating assets (excluding amounts not used in the company's main activity), while in ROA the denominator is the total assets." Zdanowicz (1998, p. 112) clarifies that there is a conceptual difference between ROI and ROA, namely: “(...) the former is associated only with the specific activity, in terms of Net Operating Revenue (NOR), Net Operating Income (NOI) and Net Operating Assets (NOA), while the latter includes the company's total sales, profits and assets in a determined period." 
According to Marion (2001, pp. 137-38), it is essential to use a coherent numerator with the denominator. If using the net income as the numerator, the total assets will make up the denominator, which must be the average total assets since the income was not generated by either the final or the initial assets, but rather by the average of the assets used during the year. Hence, in line with this affirmation, this work uses the formula proposed by Marion.

Considering that the numerator to be used is the result given by the income statement, the way it is reported directly affects the information conveyed to users. Below some Brazilian companies are presented in order to demonstrate the effects caused by using the different forms of showing profit.

\section{APPLICATION TO BRAZILIAN COMPANIES}

This study used 20 Brazilian companies listed as the best and biggest in their sectors, in the magazine Exame Melhores e Maiores for June 2004, with data referring to 2003. Of these companies, only those traded on the São Paulo Stock Exchange (Bovespa) were chosen. The data were obtained via Internet at the Bovespa site. The companies were:

AmBev - the largest company in the food, beverages and tobacco sector.

Aracruz - the best company in the pulp and paper sector.

Grendene - the best company in the textiles and clothing sector.

Natura - the best company in the pharmaceutical, hygiene and cosmetics sector.

(1) Petrobras - due to its importance in Brazil and because it is considered the largest company in the chemicals and petrochemicals sector and also the retail foreign trade sector.

Petroflex - the best company in the plastics and rubber sector.

Semp Toshiba - the best company in the electrical and electronics sector.

Vicunha - the largest company in the textiles and clothing sector.

Below are the income statements of the companies chosen, after the adjustments required by the three forms of reporting discussed before.

After the adjustments necessary in reporting income of related companies, we calculated the ROA according to the concept proposed by Gitman, Matarazzo, Silva, Zdanowicz and Marion, that is, using the average value of the total assets, except in the calculation of ROA based on accounting income, in which the average value of the total assets was used minus fixed investments (part of permanent assets). The results are summarized in the table below:

Table 1 - Rates of return on assets

\begin{tabular}{l|l|l|l}
\hline & $\begin{array}{c}\text { Operating } \\
\text { income }\end{array}$ & $\begin{array}{c}\text { Comprehensive } \\
\text { income }\end{array}$ & Net income \\
\hline AmBev & $10.89 \%$ & $10.37 \%$ & $10.37 \%$ \\
\hline Aracruz & $15.06 \%$ & $13.94 \%$ & $12.49 \%$ \\
\hline Grendene & $17.12 \%$ & $32.38 \%$ & $24.65 \%$ \\
\hline Natura & $22.29 \%$ & $9.32 \%$ & $9.32 \%$ \\
\hline Petrobras & $16.39 \%$ & $17.30 \%$ & $15.24 \%$ \\
\hline Petroflex & $4.59 \%$ & $8.64 \%$ & $8.22 \%$ \\
\hline Semp Toshiba & $2.85 \%$ & $2.88 \%$ & $2.88 \%$ \\
\hline Vicunha & $0.47 \%$ & $1.77 \%$ & $1.58 \%$ \\
\hline
\end{tabular}

None of the three ways of reporting can be clearly said to provide a higher ROA. The differences depend on the asset structure and accounting events of each company. 
Table 1 does show a high proximity of the results obtained by the comprehensive income and net income methods. The reason is that Brazilian legislation requires the booking of gains and losses from extraordinary items in the income for the year. The differences occur when there are entries to be made directly in net equity, as is the case of amounts received from subsidies, revaluation of permanent assets or distribution of amounts held in reserves.

The data in Table 1 show that operating income was greater than net income in four companies and less in the other four. The reason is the amounts (positive or negative) booked as non-operating items in the income statements, which are excluded from the calculation of operating income while they do compose the calculation net income.

In the comparison between net and comprehensive income, of the companies in the sample, five increased their ROA, due to the fact that generally the items booked directly in net equity are to constitute or increase reserves and in this way will only be added in the calculation of comprehensive income.

The variations that stand out most in Table 1 regard Grendene and Vicunha. In the case of Grendene, there is a relevant positive amount in equity pick-up which is excluded in calculating operating income, while it received a significant amount of subsidies, which is only considered in comprehensive income. What stands out in the case of Vicunha is the proportion of the variations, since their reasons are the same as for Grendene, i.e., it had nonoperating revenues and also received subsidies.

In evaluating the companies individually, the differences in the ROA because of using different accounting practices become more evident. Some of these differences are:

AmBev makes it a practice of account for the amount of subsidies its subsidiaries receive as 'other operating revenues'; this practice differs from the other firms analyzed. This directly interferes in the income statements, specifically in the statement of current operating income and net income. The amount received by the companies controlled by AmBev and that it considered 'other operating revenues' in 2003 was $\mathrm{R} \$ 175,974$. This entry caused a 9.85\% increase in the ROA for current operating income and $14.24 \%$ for net income. If AmBev had booked the subsidies received by its subsidiaries under net equity, as did the other companies, its ROA in the current operating income concept would be $9.91 \%$, and in net income $9.08 \%$. A less attentive investor might consider this as ordinary revenue, only in the near future to discover that it was an extraordinary item.

(1) Petroflex has a similar way as AmBev of treating government subsidies. In 2003, Petroflex received $\mathrm{R} \$ 3,212$ in subsidies, which were booked as 'other operating revenues'. Adjusting this amount in current operating income, the ROA would change to $4.15 \%$, a reduction of $9.57 \%$; and using net income, the ROA would change to $7.79 \%$, a reduction of $5.31 \%$.

There is an inverse effect between Petroflex and Vicunha. These companies, when they earmark part of their income to employee and executive profit sharing, book this amount as operating expenses, thus diminishing the current operating income. Petroflex earmarked $\mathrm{R} \$ 4,970$ for this purpose, while for Vicunha the figure was $\mathrm{R} \$ 3,395$. These entries caused an increase in the ROA of Petroflex of $14.80 \%$ and of Vicunha of $33.86 \%$.

\section{FINAL CONSIDERATIONS}

As described above, the current operating income concept involves measuring the company's efficiency, and to do this only the changes in value and the events not controllable by management resulting in decisions in the current period should be included. As shown on this statement, all the amounts to be used should be booked at their current worth, which 
brings a series of difficulties for companies using this method, because they would have to adapt their information systems to have this information at any moment, and would also have to assign staff to update the data in the system constantly.

A fact that needs to be shown better by the accounting statements, to enable them to make the proper adjustment, is the impact of changes in accounting standards on the statements. Normally this impact is booked as 'adjustments from previous years', which according to Brazilian legislation is the recommended procedure. However, for the adjustment in the current operating income statement, the amounts of these adjustments need to be shown more clearly.

If an investor using this income statement can evaluate the possible return on investment only by analyzing the efficiency of the company's management, and events outside its main activity can interfere directly in the result obtained, then this may not be the best way to base an investment decision.

The second concept presented is comprehensive income. By this concept, all variations occurring in the company's net equity in the period should be booked in the income statement, except capital movements and distribution of dividends. This statement apparently would be more advisable for calculating ROA, but in practice it can bring some false impressions. Brazilian legislation allows, and in some cases requires, the revaluation of companies' fixed assets. In doing so, the company books the counterpart directly in the net equity. Had this entry been made in the income statement, the result for the period could be distorted, increasing the profit, without effectively increasing the company's capacity for payment.

The third form presented is the concept of net income. This is considered a mixed form because it uses some concepts of current operating income and some of comprehensive income. Net income considers operational movements and some non-operating events as income for the period, as the case of disposal of fixed assets. Other events are booked directly in net equity, as is the case of subsidies received or the counterpart to revaluation of fixed assets. Although it does not permit a clear distinction between the change in wealth and maximization of income, this is apparently the most advisable form for investors to use, because it brings the effects of management's actions without being corrupted by events that do not directly affect the company's result.

Chart 1 presents the main similarities and differences among the three concepts in relation to accounting practices and evaluation of the elements of the income statement. This chart does not intend to close the discussion about these similarities and differences, only to present them more objectively. 
Chart 1 - Comparison among the concepts of current operating income, comprehensive income and net income

\begin{tabular}{|c|c|c|c|}
\hline & $\begin{array}{l}\text { Current } \\
\text { operating } \\
\text { income }\end{array}$ & $\begin{array}{l}\text { Comprehensive } \\
\text { income }\end{array}$ & Net income \\
\hline \multicolumn{4}{|l|}{ Amount to be considered } \\
\hline of Revenues & Current & Current & Current \\
\hline of Costs and Expenses & Current & Cost & Cost \\
\hline \multicolumn{4}{|c|}{ Facts to be considered as income for the period } \\
\hline Disposal of permanent assets & $\begin{array}{l}\text { Not } \\
\text { considered }\end{array}$ & Considered & Considered \\
\hline Donations and subsidies received & $\begin{array}{l}\text { Not } \\
\text { considered }\end{array}$ & Considered & Not considered \\
\hline Adjustments from previous years & $\begin{array}{l}\text { Not } \\
\text { considered }\end{array}$ & Considered & Not considered \\
\hline Revaluation of assets & $\begin{array}{l}\text { Not } \\
\text { considered }\end{array}$ & Considered & Not considered \\
\hline
\end{tabular}

Returning to the objective of this study, namely to analyze the effects of using different ways of reporting income on ROA, there are definite differences. This is obvious, because the income is the numerator in this formula.

The main findings here are that there are various ways of measuring and showing income that can be used simultaneously and that can generate quite different information, with none of them being deemed incorrect from a conceptual standpoint. The ideal practice would be to present all these statements in complementary form, permitting each group of users to extract the information of most interest.

Users, then, must be aware that there are alternative ways of measuring and reporting the same information, and based on individual need, they should judge whether the information presented by each company is sufficient.

\section{REFERENCES}

ACSB - Accounting Standards Board of Canada. Background Information and Basis for Conclusions. Published on August 11, 2004. Available at <www.acsbcanada.org/multimedia/Download_Library/Standards/Accounting/English/e_Com pIncBasis.pdf>. Site accessed on 01/10/2005.

BÊRNI, Duilio de Avila (Coord.). Técnicas de pesquisa em economia. São Paulo: Saraiva, 1992.

BRAGG, Steven M. Return on Net Assets - RONA. Value Based Management.net. Available at <www.valuebasedmanagement.net/methods_rona.html>. Accessed on 01/10/2005.

COELHO, Antonio Carlos; GALDI, Fernando Caio; ALMEIDA, Edir Antonia. Notes from the accounting theory class given by Prof. Dr. L. Nelson Carvalho, in the postgraduate course at FEA-USP. 11/08/2004.

EDWARDS, Edgar O.; BELL, Philip W. The Theory and Measurement of Business Income. 7th ed. Los Angeles: University of California Press, 1973. 
FASB - Financial Accounting Standards Board. Statement of Financial Accounting Concepts no. 1 - Objectives of Financial Reporting by Business Enterprises. November 1978. Available at <www.fasb.org/pdf >. Accessed on 12/15/2004.

Statement of Financial Accounting Concepts no. 3 - Elements of Financial Statements of Business Enterprises. December 1980. Available at 〈www.fasb.org/pdf $\rangle$. Accessed on 12/15/2004.

Statement of Financial Accounting Strandards no. 130 - Reporting Comprehensive Income. June 1997. Available at <www.fasb.org/pdf>. Accessed on 12/15/2004.

FIPECAFI - Fundação Instituto de Pesquisas Contábeis, Atuariais e Financeiras. Manual de contabilidade das sociedades por ações: aplicável à demais sociedades. Director in charge: Sérgio de Iudícibus; technical coordinator: Eliseu Martins; working team supervisor: Ernesto Rubens Gelbcke. 5th ed. São Paulo: Atlas, 2000.

FREZATTI, Fábio. Depoimento de Joel Contente. Available at <www.institutomvc.com.br>. Accessed on 01/08/2005.

GITMAN, Lawrence J. Princípios de Administração Financeira. 7th ed. São Paulo: Harbra Ltda., 2002.

HENDRIKSEN, Eldon S.; VAN BREDA, Michael F. Teoria da contabilidade. Tradução de Antonio Zoratto Sanvicente. 5th ed. São Paulo: Atlas, 1999.

IUDÍCIBUS, Sérgio de. Teoria da contabilidade. 7th ed. São Paulo: Atlas, 2004.

KASSAI, José Roberto; KASSAI, Sílvia; ASSAF NETO, Alexandre. Índice de especulação do valor agregado - IEVA. Revista Contabilidade \& Finanças. São Paulo, Number 30, September-December 2002.

KASSAI, José Roberto; KASSAI, Sílvia; SANTOS, Ariovaldo dos; ASSAF NETO, Alexandre. Retorno de Investimento: abordagem matemática e contábil do lucro empresarial. São Paulo: Atlas, 1999.

MARION, José Carlos. Análise das demonstrações contábeis - Contabilidade empresarial. São Paulo: Atlas, 2001.

MATARAZZO, Dante Carmine. Análise financeira de balanços: abordagem básica e gerencial. 6th ed. São Paulo: Atlas, 2003.

REIS, Arnaldo. Demonstrações Contábeis: estrutura e análise. São Paulo: Saraiva, 2003.

REVISTA EXAME MELHORES E MAIORES. Editora Abril, São Paulo, July 2004.

SILVA, José Pereira da. Análise financeira das empresas. 3rd ed. São Paulo: Atlas, 1995.

ZDANOWICZ, José Eduardo. Estrutura e análise das demonstrações contábeis. Porto Alegre: Sagra Luzzatto, 1998. 